\title{
O teólogo Jürgen Moltmann e o seu caminhar teológico realizado na esperança Acenos teo-biográficos ${ }^{1}$
}

Cesar Kuzma

\section{Resumo}

Este artigo traz uma breve reflexão sobre o teólogo Jürgen Moltmann e o seu caminhar teológico, realizado na esperança. Propõe-se, para tanto, destacar acenos teo-biográficos do autor. Jürgen Moltmann desenvolve a sua teologia a partir de uma experiência pessoal, quando se vê envolto por Deus e desperta novamente para a vida, em esperança. Este despertar em esperança é a força que o mantém vivo e é o caminho que o conduz à fé cristã, consequentemente, à teologia. De início, faremos uma aproximação com o teólogo Moltmann, destacando aspectos particulares de sua vida e como ele chega até a teologia, de modo especial, a sua Teologia da Esperança. Logo em seguida, trataremos de assuntos peculiares, próprios de uma experiência pessoal, em campo de concentração, que o faz encontrar-se com a esperança e é o ponto inicial de sua reflexão teológica.

Palavras-chave: Jürgen Moltmann, Teologia, Esperança, Teologia da Esperança.

\footnotetext{
${ }^{1}$ Este artigo tem como base o que construímos na nossa tese de doutorado, defendida em 13 de abril de 2012, na PUC-Rio. Disponível em: <http://www.maxwell.lambda.ele.puc-rio. br/19888/19888_1.PDF>. Acesso em 07 de agosto de 2012.
} 


\begin{abstract}
This article brings a brief reflection about the theologian Jürgen Moltmann and his way in the theology, practiced in hope. It proposes to do so, with highlight to points theo-biographical of the author. Jürgen Moltmann develops his theology from a personal experience, when he is surrounded by God and awakens again to life, in hope. This awakening in hope is the strength that keeps him alive and is the way that leads to the Christian faith, therefore, to theology. At first, we will approach with the theologian Moltmann, highlighting particular aspects of your life and how he comes to theology, in particular, his Theology of Hope. Shortly thereafter we will discuss his own personal experience, in a concentration camp, his meeting with the hope and is the starting point of his theological reflection.
\end{abstract}

Keywords: Jürgen Moltmann, Theology, Hope, Theology of Hope.

\title{
Introdução
}

Em setembro de 2011, fomos agraciados com a visita do teólogo alemão Jürgen Moltmann ao Brasil, de modo específico, na cidade do Rio de Janeiro, onde ele percorreu alguns institutos teológicos e, também, a PUC-Rio, que promoveu este evento. Estar diante de Moltmann, naquele instante, foi saborear uma teologia encarnada, forte na fé e rica em amor e esperança. De modo bastante simples e disposto, Moltmann conduziu os seus trabalhos e nos mostrou traços de sua teologia, tanto de seu início como nas suas novas projeções. No entanto, ao ouvi-lo, o que mais chamou a atenção foi à emoção com que ele descreveu o seu momento inicial, quando a partir de uma experiência pessoal, durante e após a Segunda Guerra Mundial, ele teve o seu contato com Deus e teve o seu despertar na esperança. Este é um ponto básico para se conhecer Moltmann e para compreender o seu caminhar teológico. É daí que se desenvolve a sua teologia e é daí que se compreende a sua noção de esperança.

Diante disso, neste artigo, optamos por seguir este percurso do autor, destacando, assim, acenos teo-biográficos do seu caminhar teológico, realizado na esperança ${ }^{2}$.

\footnotetext{
${ }^{2}$ Neste artigo, estaremos nos concentrando apenas nesta parte inicial de sua vida. Aspectos específicos da Teologia da Esperança, sua obra de referência, podem ser encontrados em um dos nossos artigos, a saber: KUZMA, C. A esperança cristã na Teologia da Esperança. Pistis \& Práxis, Curitiba, v. 1, n. 2, p. 443-467, jul/dez, 2009.
} 


\section{Jürgen Moltmann: uma breve aproximação}

Jürgen Moltmann é um dos teólogos mais respeitados e influentes do mundo contemporâneo, ele possui uma teologia expressiva, com forte teor dogmático e um diálogo profícuo com a sociedade atual. Depois de grandes líderes anteriores, como Barth, Cullmann, Tillich e Bonhoeffer, é provável que ele seja a figura mais representativa da teologia protestante contemporânea. Moltmann é de confissão cristã reformada, mas possui grande abertura reflexiva e um importante contato ecumênico. Nasceu em 8 de abril de 1926 na cidade de Hamburgo, Alemanha, sendo, na sua juventude, um apaixonado por Matemática e Física, sob a influência de autores como Albert Einstein e Max Planck; porém, teve a necessidade de logo cedo abandonar os sonhos juvenis, quando aos dezessete anos, após ver a sua cidade destruída em julho de 1943 pela operação Gomorra e, também, por ser soldado recém incorporado, foi convocado para o front do exército alemão, no qual, depois de seis meses, foi feito prisioneiro de guerra pelo exército inglês. Inicialmente, foi levado para a Holanda e Bélgica, depois para a Escócia e, logo em seguida, para o campo de concentração de Norton Camp, na Inglaterra, perto de Mansfield, em Nottinghamshire. O regresso para a Alemanha só aconteceu em $1948^{3}$.

Tal experiência marcou profundamente o encontro de Moltmann consigo mesmo e com o mundo que o cercava naquele instante, cuja verdadeira realidade era abstraída da juventude alemã e de grande parcela da sociedade pelos nazistas e seus ideais. Este momento marcou também o encontro do jovem Moltmann com Deus, alguém que ainda era desconhecido para ele, mas que aos poucos se revelava em esperança, para um novo começo, para uma nova vida. Nas suas palavras: "Em minha juventude, fui salvo pela esperança de

\footnotetext{
${ }^{3}$ Cf. MOLTMANN, J. Weiter Raum. Eine Lebensgeschichte. München: Gütersloher Verlagshaus, 2006, p. 20-46. Sobre estes marcantes episódios da vida do autor, outras obras trazem referência: Id. Experiências de reflexão teológica. Caminhos e formas da teologia cristã. São Leopoldo, RS: UNISINOS, 2004, p. 17-18; Id. Vida, esperança e justiça. Um testamento para a América Latina. São Bernardo do Campo, SP: Editeo, 2008, p. 9-12; Id. A fonte da vida: o Espírito Santo e a teologia da vida. São Paulo: Loyola, 2002, p. 9-17. Id. No fim, o início. Breve tratado sobre a esperança. São Paulo: Loyola, 2007, p. 49-52. Id. (Ed.). Biografia e Teologia. Itinerari di teologi. Brescia: Queriniana, 1998, p. 20-28. A importância desses relatos é que Moltmann sempre retorna a eles para justificar a sua teologia e para dar sentido a sua experiência de Deus e de esperança. Entendemos que, a biografia do autor é um caminho obrigatório para se compreender a noção de escatologia que transparece em suas obras, principalmente, na "Teologia da Esperança”. Durante a sua última passagem pelo Brasil, em 2011, na cidade do Rio de Janeiro, esta reflexão foi tomada como base em quase todas as suas falas.
} 
Cristo. Ele a plenificou até hoje com a energia do Espírito divino. Ele me permite saudar todas as manhãs em que me é dado viver, com a alegria adventícia do Reino de Deus"'. Em outra passagem ele diz: "Eu ainda estava à procura, porém sentia que Deus me atraía e que eu não o procuraria se ele já não me tivesse achado"s. Ele diz também que, essas experiências de morte e de resignação converteram-se para ele no seu "primeiro locus theologicus", a raiz dos seus esforços teológicos, e continua sendo até hoje no recôndito de sua alma ${ }^{6}$.

Vale destacar que dentre os prisioneiros de Norton Camp encontravam-se alguns professores de teologia, através dos quais, depois de forte experiência, ele teve a possibilidade de iniciar seus estudos teológicos, cujas esperanças foram se manifestando e se construindo: "Naquele tempo, li de tudo: poesias e romances, matemática e filosofia, e grandes quantidades de teologia, praticamente de manhã até a noite"?.

Já em 1948, voltou à Alemanha e decidiu por prosseguir seus estudos em Göttingen até 1952, ano em que os concluiu ${ }^{8}$. Em 1953 trabalhou como pastor em uma pequena comunidade reformada de Bremen-Wasserhorst ${ }^{9}$; usando de suas palavras: "uma pequena comunidade rural composta de 400 almas vivendo em 50 propriedades e de 2.000 a 3.000 vacas" ${ }^{10}$. Para ele, este fato foi de suma importância, pois acabava de sair pós-graduado de uma universidade e se vê as voltas com outra realidade, totalmente desafiadora, bem simples. Esta experiência fez com que tivesse "conhecimento da teologia do povo na luta por suas famílias e seu sustento diário, nas memórias de seus mortos e nos cuidados pelas suas crianças" ${ }^{11}$. Eis um ponto que vale a pena ser destacado.

Academicamente, ele ensinou História dos Dogmas e Teologia Sistemática na Kirchiliche Hochschule de Wuppertal, onde foi colega de Wolfhart Pannenberg. Ali permaneceu de 1958 até $1964^{12}$, ano em que foi chamado para a Universidade de Bonn ${ }^{13}$. Mais tarde, desde 1967, tornou-se professor na Universidade de Tübingen ${ }^{14}$, da qual hoje permanece como professor emérito.

\footnotetext{
${ }^{4}$ Id. Vida, esperança e justiça, p. 9.

${ }^{5} \mathrm{Id}$. A fonte da vida, p. 14.

${ }^{6}$ Cf. Id. Experiências de reflexão teológica, p. 18.

${ }^{7}$ Id. A fonte da vida, p. 15.

${ }^{8}$ Cf. Id. Weiter Raum. Eine Lebensgeschichte, p. 49-60.

${ }^{9}$ Cf. Ibid., p. 61-73.

${ }^{10} \mathrm{Id}$. Experiências de reflexão teológica, p. 18.

${ }^{11}$ Ibid.

${ }^{12}$ Cf. Id. Weiter Raum. Eine Lebensgeschichte, p. 77-87.

${ }^{13}$ Cf. Ibid., p. 97.

${ }^{14}$ Cf. Ibid., p. 149.
} 
Também no período de 1967-1968 foi convidado na condição de professor visitante à Duke University, EUA. Jürgen Moltmann é casado com Elizabeth Moltmann-Wendel, também teóloga. Eles se conheceram durante o período de estudos em Göttingen. Eles têm quatro filhos.

Moltmann é considerado o "fundador" da Teologia da Esperança, movimento teológico contemporâneo que surgiu na Alemanha durante a segunda metade do século XX e, também, o seu principal expoente. Este movimento se caracteriza por diversas expressões, o que acontece em várias partes onde é apresentado e interpretado, traduzindo-se, na maioria das vezes, por uma teologia pública (Öffentliche Theologie), uma teologia que traz a esperança como ponto de ação na perspectiva do Reino de Deus Vindouro. Para Moltmann, "a teologia cristã é theologia pública por causa do Reino"15. Outra expressão teológica contemporânea, decorrente deste movimento, que também lhe é atribuída, é a Teologia da Cruz, desenvolvida em período posterior. Ele diz: "Uma Teologia da Cruz era minha preocupação antiga, mais antiga do que a Teologia da Esperança" ${ }^{16}$. Ele justifica esta intenção com uma questão pessoal, uma busca de Deus no fundo de sua existência e de sua experiência de morte e de abandono do campo de concentração, conforme demonstraremos a seguir. No entanto, o que o fez buscar uma nova compreensão a partir da cruz foi um não contentar-se com a forma como ela era apresentada, muitas vezes marcada com o sacrifício pelo pecado, num tom de remissão de culpa, mas não de esperança ${ }^{17}$. Esta teologia, no seu desenvolver, tinha a intenção de "corrigir" certo entusiasmo apresentado por ele na Teologia da Esperança e que poderia ser visto de maneira mais ampla e coerente com a proposta cristã diante das realidades mundanas, muitas delas marcadas pela dor e pelo sofrimento ${ }^{18}$. Deste "suposto entusiasmo" é de onde partiram muitas de suas críticas, principalmente da América Latina ${ }^{19}$. Há também a Teologia Política que, juntamente com Johann Baptist Metz se tornou uma expressão teológica de grande repercussão ${ }^{20}$. Com efeito, mesmo o autor ampliando a

\footnotetext{
${ }^{15}$ Id. Experiências de reflexão teológica, p. 26.

${ }^{16}$ Id. Weiter Raum. Eine Lebensgeschichte, p. 185. Citação original: "Eine Theologie des Kreuzes war mein altes Anliegen, älter als die Theologie der Hoffnung". Tradução nossa.

${ }^{17}$ Cf. Ibid.

${ }^{18}$ A obra que marca este momento na sua teologia é "O Deus Crucificado", "Der gekreuzigte Gott" de 1972.

${ }^{19}$ Cf. Id. Temas para una Teologia de la Esperanza. Buenos Aires: La aurora, [s/d], p. 63-81.

${ }^{20}$ Cf. Id. Weiter Raum. Eine Lebensgeschichte, p. 156. Sobre Johann Baptist Metz e a Teologia Política indicamos: METZ, J. B. Teologia Política. Porto Alegre: Escola Superior de Teologia São
} 
sua perspectiva teológica e na atualidade passando a abrir novas perspectivas, como, por exemplo, com a questão ecológica ${ }^{21}$, é na Teologia da Esperança que se encontram os pilares do seu pensamento. O que vem depois é um somar-se, um ampliar da sua reflexão, porém sempre a partir da esperança.

O ponto principal de sua carreira teológica e que marca a sua ligação com a corrente teológica citada acima (e as demais correntes citadas) é com a publicação de sua obra Teologia da Esperança (Theologie der Hoffnung) em $1964^{22}$. Nela, o tema da esperança aparece como elemento hermenêutico, levando-a, assim, ao centro da teologia, conforme suas palavras: "já não mais teorizava sobre a esperança, mas a partir dela" ${ }^{23}$. Ou também: "O todo da teologia em um único enfoque" ${ }^{24}$.

Moltmann é um teólogo que possui uma grande aceitação no meio católico, principalmente pelo seu comportamento ecumênico diante dos teólogos católicos europeus. Fato que não o impede, como teólogo protestante, de fazer críticas à Igreja Católica quando esta, no seu entender, não adere ao movimento ecumênico ${ }^{25}$. Em contrapartida, evidencia-se em sua carreira teológica uma aproximação com teólogos católicos no meio acadêmico, não só por consequência de pensamentos (J. B. Metz é um exemplo), mas também por amizade, estima e ambiente de trabalho. Sua última universidade, por exemplo, Tübingen Universität, sustenta (como em várias universidades alemãs) uma faculdade católica de teologia e uma faculdade evangélica, onde

Lourenço de Brindes; Caxias do Sul: UCS, 1976; Id. Para além de uma religião burguesa: sobre o futuro do cristianismo. São Paulo: Paulinas, 1984.

${ }^{21}$ Moltmann tem dedicado a sua teologia a questão ecológica desde 1985, com a publicação do livro "Deus na criação: doutrina ecológica da criação". Título original: "Gott in der Shöpfung Ökologische Shöpfunglehre”, de 1985. A tradução brasileira é de 1993: MOLTMANN, J. Deus na criação. Doutrina ecológica da criação. Petrópolis, RJ: Vozes, 1993. De lá para cá, esta é uma temática que tem tomado conta da vida do autor e ele relaciona a sua teologia - no aspecto escatológico, público e político - dentro desta perspectiva.

${ }^{22}$ Cf. MOLTMANN, J. Weiter Raum. Eine Lebensgeschichte, p. 103.

${ }^{23}$ Id. "My theological career", 1991, p. 170. Apud: MUELLER, E. R. Apresentação da 3 a edição. São Leopoldo, 2005. In: MOLTMANN, J. Teologia da Esperança. Estudos sobre os fundamentos e as consequências de uma escatologia cristã. 3. ed. São Paulo: Teológica, Loyola, 2005, p. 14-15. ${ }^{24}$ Id. Teologia da Esperança, p. 24.

${ }^{25}$ Ilustramos este fato com seu artigo na revista Concilium, sob o título "A Igreja como communio". A intenção deste artigo era de responder a carta da Congregação para Doutrina da Fé de 15 de junho de 1992, pela maneira como foram tratadas as comunidades protestantes e evangélicas, segundo Moltmann, de maneira não respeitosa. Ele argumenta que a carta ignora acentos já formulados pelo Vaticano II, tendo, portanto, um teor não ecumênico. Ver: MOLTMANN, J. A Igreja como communio, Concilium, Petrópolis, RJ, n. 245, p. 161-163, 1993/1. 
professores e alunos podem comungar deste ambiente. Nesta universidade ele se encontra com Hans Küng, Joseph Ratzinger, entre outros. Também no livro Weiter Raum (2006), que é uma espécie de autobiografia teológica, ele reproduz fotos e relatos de alguns eventos desta natureza. Destacamos o encontro que teve com o Papa Paulo VI ${ }^{26}$, durante audiência em março de 1972, e com o Papa João Paulo II em 198227, durante Congresso Teológico Internacional de Pneumatologia. Moltmann possui também um importante diálogo com a Teologia Latino-Americana da Libertação ${ }^{28}$, o que o colocou mais próximo de alguns teólogos católicos.

Como a intenção deste artigo é despertar para o caminho que Moltmann percorre com a esperança, que para ele se traduz em esperança no futuro de Deus, ao qual somos chamados a participar (em missão) e, por percebermos que, o seu modo de teologizar parte, primeiramente, de uma questão pessoal, do encontro do teólogo com Deus, nós apresentamos abaixo fragmentos de um breve relato:

O começo de minha busca teológica por Deus coincidiu com o fim pavoroso de minha cidade natal, Hamburgo, em 1943. Pode-se dizer que sou um sobrevivente de "Sodoma e Gomorra". Essa menção não tem nada a ver com a poesia religiosa, mas com uma realidade dolorosa. Quando essa lembrança me vem à mente, me assaltam temor e tremor.

[...] Nas últimas semanas de julho de 1943, aquela cidade foi destruída pelo fogo provocado por "Sodoma e Gomorra", nome dado à operação de bombardeio da força aérea britânica. A bomba que esfacelou um de meus colegas, ao meu lado, me poupou de modo indescritível. Naquela noite de morte em massa, eu gritei pela primeira vez por Deus: "Meu Deus, onde tu estás? Onde está Deus?"

Durante três anos como prisioneiro de guerra na Escócia e na Inglaterra, procurei uma resposta. Em todas as noites, travei uma batalha com Deus como Jacó, que lutou contra o Anjo do Senhor no Vau de Jaboque. Tratou-se de uma luta contra o lado mais obscuro de Deus, contra sua face abscôndita, contra o "não" de Deus que tivemos que suportar durante a guerra e na miséria do tempo de prisão. Nós escapamos da morte no

\footnotetext{
${ }^{26}$ Cf. Id. Weiter Raum. Eine Lebensgeschichte, p. 126.

${ }^{27}$ Cf. Ibid., p. 127.

${ }^{28}$ Cf. Id. Experiências de reflexão teológica, p. 157-251. Também: Id. O Espírito da vida. Uma pneumatologia integral. Petrópolis, RJ: Vozes, 1999, p. 110-114. Id. Weiter Raum. Eine Lebensgeschichte, p. 215-224.
} 
conflito, mas para cada um que sobreviveu houve centenas que morreram. Nós escapamos do inferno, mas pusemo-nos atrás do arame farpado e perdemos a esperança.

[...] O meu mundo interior desabou. Eu recolhi meu coração que sangrava dentro de uma carapaça de imperturbabilidade e apatia. Isso foi uma forma de prisão interna para a alma, somada à prisão externa. Uma pessoa pode se tornar tão apática e indiferente que não é mais capaz de sentir nada: nem alegria, nem dor. Então não se vive mais, torna-se como que um morto-vivo. $[\ldots]$

Em maio de 1945, tivemos que empurrar um veículo no miserável campo de prisioneiros da Bélgica. Eu o fiz calado e sem a menor vontade. De repente, notei que estava entre lindas cerejeiras florescentes. A vida plena "olhou" para mim. Eu caí, quase inconsciente, mas senti a primeira centelha de vida novamente em mim.

$\mathrm{Na}$ Escócia, trabalhamos na construção de ruas junto com o povo nativo. Eles nos chamavam pelo nome mesmo que nós trouxéssemos em nossas costas apenas números. Eles trataram seus antigos inimigos com uma hospitalidade tão natural, uma solidariedade tão humana que me senti profundamente envergonhado. Por meio deles, fomos transformados de figuras petrificadas em pessoas que novamente podiam sorrir.

Então, recebi uma Bíblia como presente de um capelão do exército inglês. Eu não sabia exatamente o que fazer com ela. À noite, li primeiro os salmos de lamentação do Antigo Testamento. Com a leitura do Salmo 39 (v. 3,5,12), me senti tocado[...] $]^{29}$.

Isso foi ao fundo de minha alma. Depois, li o Evangelho de Marcos e encontrei a passagem que menciona o grito de morte de Jesus: "Meu Deus, porque me desamparaste?". Foi naquele momento que pude saber com certeza: "Aí está um que me entende".

\section{$[\ldots]$}

Eu me tornei tão fascinado por aquela experiência de vida que perdi meu interesse pela Matemática e pela Física. Decidi estudar Teologia para investigar o que é verdadeiro na fé cristã. [...] Eu me inscrevi e fui

\footnotetext{
${ }^{29}$ Pela tradução brasileira da Bíblia de Jerusalém a citação que o autor faz refere-se aos versículos 4, 6 e 13: "Meu coração queimava dentro de mim, ao meditar nisso o fogo se inflamava... minha duração é nada diante de ti... Ouve a minha prece, Iahweh, dá ouvido aos meus gritos, não fiques surdo ao meu pranto! Pois sou forasteiro junto a ti, inquilino como todos os meus pais".
} 
levado em 1946 por um soldado inglês para Norton Camp, que ficava nas proximidades de Nottingham, num lindo parque do Duque de Portland.

$[\ldots]$

Eu nunca experimentei Deus como opressivo ou alienante, mas sempre como esse lugar espaçoso da liberdade, no qual se pode respirar e ressurgir ${ }^{30}$.

Moltmann diz que, para ele, a teologia sempre é um caminho aberto e convidativo, seus métodos partem inicialmente do nível biográfico-pessoal (por essa razão reproduzimos o relato acima), contextual-político e pelo kairós histórico que vive no momento ${ }^{31}$. Passaremos, a partir de agora, a apresentar de maneira detalhada o transcorrer deste percurso teológico, no intuito de desvelar a escatologia no percurso de sua teologia ${ }^{32}$. Não se tratam apenas de traços biográficos do autor em questão, mas sim, uma reflexão teológica com base em sua teologia, a partir de relatos de vida do próprio autor, através dos quais se descortina a esperança presente na sua escatologia e que, consequentemente, amadurece teologicamente no percurso de sua história. Nas suas palavras: "Primeiro vem a experiência, depois a teologia; primeiro a paixão, em seguida a ação"33.

Um teólogo verdadeiro deve ter elaborado a sua luta com Deus, a sua experiência de Deus, seus medos de Deus e sua alegria em Deus. Ele deve ter se exposto pessoalmente à causa que representa, e não reprimir as suas experiências negativas diante de Deus nem calar o seu gosto positivo em Deus (Sl 37,4). É bom quando se consegue reconhecer, numa teologia, o teólogo, a teóloga, e, nos agentes poimênicos, a própria alma envolvida ${ }^{34}$.

\footnotetext{
${ }^{30}$ Id. Vida, esperança e justiça, p. 10-12. Grifamos no final a expressão "lugar espaçoso" por se tratar de uma expressão que Moltmann se refere muito para explicitar a sua experiência com Deus. Um dos livros que estamos utilizando como base de suas experiências pessoal e teológica traz esta expressão no próprio título: “Weiter Raum”.

${ }^{31}$ Cf. Id. Experiências de reflexão teológica, p. 10.

${ }^{32}$ Ver também: PIAZZA, O. F. "MOLTMANN Jürgen”. In: PACOMIO, Luciano; OCCHIPINTI, Giuseppe. Lexicon. Dizionario dei Teologi. Pieme, p. 897-899.

${ }_{33}^{33}$ MOLTMANN, J. Experiências de reflexão teológica, p. 32.

${ }^{34}$ Ibid. Não tivemos acesso ao texto original em alemão para entender o que foi que o tradutor quis dizer com "poimênicos". Entendemos que, trata-se de agentes de acolhimento, pastoral da acolhida, do aconselhamento, algo nesta direção.
} 
Esta foi a intenção que nos levou a chamar este artigo com o título: " $O$ teólogo Jürgen Moltmann e o seu caminhar teológico realizado na esperança: acenos teo-biográficos".

\section{O encontro de Jürgen Moltmann com a esperança}

Entendemos que este caminho parte, primeiramente, de uma experiência pessoal vivida por ele no incidente em Hamburgo (que relatamos acima), quando sua cidade natal foi destruída e, mais tarde, quando prisioneiro em um campo de concentração. É daí que surgem suas perguntas existenciais ${ }^{35}$. Um ponto marcante e central que ele sempre menciona é a questão de Auschwitz, apresentado por ele como a raiz de seus esforços teológicos. Temos aí a chave teológica para entendermos o que aconteceu com ele em Norton Camp, na Inglaterra, e como passou a refletir sobre a esperança em sua vida e na teologia. Esta sua experiência vai aos poucos ganhando espaço e dando-lhe respostas, sendo assim capaz de direcioná-lo para um futuro, que até então, para ele, parecia incerto. Ao mesmo tempo em que sente na própria pele os efeitos da guerra e na medida em que toma conhecimento das atrocidades nazistas, solidariza-se também com aqueles que, assim como ele, são vítimas da opressão. Num ambiente assim, a esperança foi a sua companheira e o seu refúgio, foi a força que o manteve vivo e, por esta razão, e até hoje, a sua companheira inseparável.

Para fortalecer a nossa discussão enfatizaremos nesta parte do trabalho o encontro de Moltmann com a esperança em dois momentos: a questão de Auschwitz e a sua própria experiência de campo de concentração.

\subsection{A esperança em Deus depois de Auschwitz}

Moltmann não foi prisioneiro nos campos de concentração de Auschwitz, mas este é um ponto de extrema importância para se compreender como se situa a esperança em Moltmann e percebermos a escatologia que se destaca em sua Teologia da Esperança e em todo o seu caminhar teológico. Sua reflexão teológica que foi aos poucos ganhando espaço é alicerçada pela sua experiência de cativeiro em campos de concentração, onde pôde ver, ao lado de seus colegas, a verdade sobre as práticas de extermínio que ocorriam dentro de certos campos nazistas, como, no caso, um dos seus maiores: Auschwitz.

${ }^{35}$ Cf. Id. Weiter Raum. Eine Lebensgeschichte, p. 186. 
O início de sua teologia acontece - conforme relatamos acima - no fundo dessas experiências. Naquele momento histórico a grande pergunta que se fazia, originaria de Emmanuel Lévinas (1906-1995) era: "Como falar de Deus depois de Auschwitz?".

Como se pode falar de Deus depois de Auschwitz? Este é o seu [de quem precisou gritar por Deus] problema. Mais ainda, porém, é seu problema como depois de Auschwitz não se pode falar de Deus. De que então é para falar depois de Auschwitz, se não de Deus?! [...] Este não-mais-poderfalar-de-Deus e, contudo-ter-que-falar-de-Deus, em face da experiência esmagante do peso da culpa na minha geração, é possivelmente a raiz de meus esforços teológicos, pois o pensar sobre Deus sempre de novo me leva de volta àquela aporia ${ }^{36}$.

Para justificar esta dificuldade, colocada por ele como algo sem saída racional, ele ainda continua parafraseando outro autor, Elie Wiesel (sobrevivente de Auschwitz III), ao dizer: "Não se pode entender [Auschwitz] com Deus. E não se compreende sem Ele" ${ }^{" 37}$. No fundo, ele tem razão, pois não há uma explicação plausível para a crueldade que foi exercida contra a vida humana neste campo e em outros. É impossível imaginar Deus lá, mas também não se compreende sem ele. Moltmann argumenta que sempre que tenta falar de Deus ou sobre ele, depara-se, novamente, às voltas com a questão de Auschwitz ${ }^{38}$. Por quê? Talvez porque ele também gritou por Deus como tantos outros gritaram e se sentiram igualmente, devido à circunstância, abandonados por Deus, supostamente, silencioso. Mas não! A compreensão que ele adquiriu com o tempo e com a reflexão teológica proveniente desta experiência, mostrou-lhe que não se trata de um Deus silencioso, mas solidário e, ao mesmo tempo, sofredor.

Como ele próprio diz, esta experiência é a raiz de seus esforços teológicos. Porém, como será possível atribuir uma ligação do que aconteceu neste lugar com uma experiência divina, capaz inclusive de suscitar esperança? Para responder

${ }^{36}$ Id. Geschichte des dreieinigen Gottes, p. 222. Apud: HAMMES, E. J. A cristologia escatológica de J. Moltmann. Teo comunicação. Porto Alegre, 2000, n. 130, v. 30, p. 606.

${ }^{37}$ Ibid.

${ }^{38}$ Como apontamos acima, Moltmann não passou por este campo, o que descobriu das atrocidades de Auschwitz veio do período em que ficou como prisioneiro em outros campos de concentração. No entanto, Auschwitz e seus campos de concentração permanecem até hoje como um marco do holocausto e da capacidade humana para a morte e para a destruição. Em Auschwitz I encontra-se até os dias de hoje a frase: Arbeit macht frei ( $\mathrm{O}$ trabalho liberta). 
a este questionamento precisamos percorrer o caminho que Moltmann fez para teologizar o sofrimento divino e sua relação na amplitude humana. $\mathrm{O}$ momento que ele reflete é a partir da morte de Cristo na cruz. Como vimos acima, há uma identificação do autor com o grito do Cristo crucificado. Esta interpretação, ainda não de cunho teológico, mas dentro de uma forte experiência, é capaz de refazer o conceito de Deus a partir da visão da solidariedade.

Quando li o grito de Jesus ao morrer: "Meu Deus, por que me abandonaste?", soube com certeza: está ali o único que me compreende. Comecei a compreender o Cristo atribulado, porque sentia que era compreendido por ele: o irmão divino na aflição, que leva consigo os cativos em seu caminho para a ressurreição. Recobrei o ânimo de viver. Fui tomado de uma grande esperança ${ }^{39}$.

Como a nossa intenção é apresentar um aceno teo-biográfico do autor, vejamos isso teologicamente, a partir de seu pensamento.

Pelo ensinamento, prática, vida e obra de Jesus de Nazaré, sabemos que a consistência do Deus anunciado por ele se concentra no amor. "Deus é amor", dirá a primeira Carta de João (1Jo 4,16). É o conteúdo da Boa Nova, como dom gratuito da abertura de Deus em relação à humanidade, porém, esta, no exercício de sua liberdade (dom de Deus), recusa-se a aceitá-la, rejeitando, com isso, o amor de Deus. Contudo, a essência de Deus consiste no amor que é eterno, ele não muda. Por isso, Jesus, que é a visibilidade concreta deste amor, assume a decisão de caminhar até as últimas consequências, chegando inclusive a ser morto, morto por causa do amor.

Para explicar este estranho amor que decide sofrer, Moltmann menciona em sua obra "O Deus Crucificado"40 a novela Demônios, de Dostoiévski (1821-1881), que diz: um Deus que não pode sofrer é mais desgraçado do que qualquer homem. Um Deus incapaz de sofrimento é um ser indolente, pois a injustiça e o sofrimento não o afetam. Seria carente de afetos, portanto, nada o pode afetar, nada o comove. Não pode chorar porque não tem lágrimas; se não pode sofrer, tampouco pode amar. Um Deus assim poderia ser o Deus de Aristóteles, mas não o Deus de Jesus Cristo ${ }^{41}$.

\footnotetext{
${ }^{39}$ MOLTMANN, J. A fonte da vida, p. 12-13.

${ }^{40}$ Título original: MOLTMANN, J. Der gekreuzigte Gott, 1972. Para as referências bibliográficas desta obra, estaremos utilizando a obra traduzida para o espanhol, de mais fácil acesso; mas em consulta com a obra no idioma original, edição de 2007. A edição brasileira, em português, foi lançada em setembro de 2011, por ocasião da visita de Moltmann ao Brasil.

${ }^{41}$ Cf. MOLTMANN, J. El Dios crucificado. Salamanca: Sígueme, 1975, p. 311.
} 
Portanto, essa concepção de Deus silencioso em Auschwitz mostraria um Deus encurvado sobre si mesmo (Deus incurvatus in se) e não é isto o que atesta a doutrina cristã, da qual o ser humano é a imagem e semelhança (cf. Gn 1,26); não é o que mostra a experiência do Êxodo e não é o que mostra o caminho do próprio Jesus. Assim dirá Moltmann: "Mas um homem pode sofrer, porque pode amar. [...] Finalmente, um Deus, exclusivamente, onipotente é em si um ser imperfeito"42. Vemos que, assim, segundo a doutrina cristã e, assistida aqui pela teologia de Moltmann que, a encarnação de Jesus é algo realizado por Deus no intuito de revelar a essência de seu ser que é amor. Não apenas revelar, mas atrair, convidar a participar desta comunhão de amor.

Este sentimento capaz de sofrer é resultado de um amor que se solidariza com quem é amado e pelo qual faz tudo para libertar. Agora, em Jesus, Deus vai mais longe nesse amor. Ele, pelo qual foi criada a história, decide fazer-se história. Assume a humanidade por inteira no ser de Deus, pois agora, Deus-Homem sente na própria carne, sarx, o que sente um ser humano, com todas as limitações provenientes dessa situação, até mesmo a íntima relação entre o ser humano e Deus ${ }^{43}$. Notamos aqui a importância do que é apontado em F1 2,6-11, no qual se destaca a kénosis do Filho. Esta kénosis atinge todo o mistério trinitário e, por fim, a nós, destinatários deste evento salvífico. Esta íntima ligação divina-humana, que nos assegura a fé, é o que sustenta a nossa esperança.

Portanto, para compreender um Deus que seja solidário com o sofrimento humano, Moltmann nos convida a observar a atitude que era depositada pelo homem de Nazaré. Nesta atitude, Jesus (Deus-Homem) não olhava o outro apenas como outro, não o via como alguém estranho a si mesmo, mas sim, aproximava-se dele, tornando-se próximo, colocando-se junto, ao lado, sendo solidário (cf. Lc 10,25-37). Nisto consiste a atitude cristã que decorre da prática de Jesus.

Retornando para a questão em Moltmann, dizemos que esta é a esperança de que falamos e que foi aos poucos extirpada em Auschwitz. Deste modo, Moltmann descobre que o caráter da esperança está em se fazer também

\footnotetext{
${ }^{42}$ Ibid., p. 312. Grifos nossos.

${ }^{43}$ Encontramos aqui outro relato de Moltmann sobre esta relação do Filho com aqueles que sofrem: "O filho de Deus, abandonado por Deus, carrega em si a eterna morte dos abandonados e condenados a fim de se tornar o Deus dos abandonados, e o irmão dos condenados. Todos os condenados e abandonados por Deus podem agora, no crucificado, experimentar a comunhão com Deus. O Deus encarnado faz-se agora presente e acessível à humanidade de cada ser humano. Não é necessário transformar-se ou assumir algum papel especial a fim de viver a humanidade, em Cristo". MOLTMANN, J. Paixão pela vida. São Paulo: ASTE, 1978, p. 60.
} 
solidário com quem está sofrendo, mas pelo ponto de vista do sofredor, a partir dele ${ }^{44}$. Ele aos poucos descobre esta esperança escondida dos muros, mas revelada na fé do Cristo ressuscitado e crucificado. Ao ver em si mesmo e nas demais vítimas traços semelhantes com Aquele que outrora, por nós, fora crucificado e morto, a esperança passou a ter outro significado. Por isso que, para ele, falar de Deus depois de Auschwitz é fundamental, pois a esperança neste Deus foi a única coisa capaz de fazer alguém sobreviver a esses tormentos, ou, talvez, a única coisa em que esperavam aqueles que morreram por causa desses.

Moltmann oferece uma importante reflexão a este respeito na sua obra "Experiências de reflexão teológica" quando fala do surgimento da "Nova Teologia Política". Ele cita, além de si próprio, o colega católico J. B. Metz e a teóloga Dorothee Sölle, que se veem obrigados a enfrentar a questão de Auschwitz e a questão dos judeus no momento em que propõem uma teologia voltada para o mundo ${ }^{45}$. Ignorar tal discussão seria um descaso e um desrespeito, além disso, era uma tarefa da teologia dar a sua resposta para as indagações, o que levava também a questionar e a incomodar o "silêncio" dos cristãos diante de tal fato. Diz: "O nome 'Auschwitz' designava para nós as condições hermenêuticas em que deveríamos considerar, na Alemanha pós-guerra, o falar cristão de Deus"46.

Para Moltmann, a fé cristã está ligada às experiências de uma situação existencial particular que transcende para uma situação social. Para ele, somente quem já esteve face a face com a morte e teve de clamar a Deus sabe que não poderá fazer uma teologia reservada e individual. Para ele, a teologia deve tornar-se uma Teologia Pública, "que compartilha os 'sofrimentos desta época' e que formula suas esperanças em Deus no lugar em que vivem os seus contemporâneos"47. O que valia daquele momento em diante não era perguntar como falar de Deus depois de Auschwitz, mas sim, como não falar de

\footnotetext{
${ }^{44}$ A Teologia Latino-Americana da Libertação parte desta perspectiva. O Cristo crucificado identifica-se com o povo que sofre e torna-se solidário a eles; o povo, por sua vez, sente esta identificação e vê em Cristo alguém que lhe é próximo.

${ }^{45}$ Em 1997 Jürgen Moltmann promoveu um Simpósio com outros teólogos para discutir a questão da origem teológica de cada um e como a compreensão da mesma mudou ou foi ampliada no decorrer dos anos. Neste evento, que depois teve as suas conferências publicadas, encontramos também J. B. Metz e Dorothee Sölle. Desta obra entitulada "Wie ich mich geändert habe", tivemos acesso à tradução italiana: MOLTMANN, J. (Ed.). Biografia e teologia. Itinerari di teologi, 1998.

${ }^{46}$ MOLTMANN, J. Experiências de reflexão teológica, p. 102-104.

${ }^{47}$ Ibid., p. 13.
} 
Deus depois de Auschwitz? No fundo, esta angústia reproduz algo vivido por ele interiormente, ao se confrontar em uma situação semelhante, quando era prisioneiro no campo de concentração.

\subsection{A esperança no campo de concentração - atrás do arame farpado}

Acima reproduzimos um pensar teológico de experiência de campo de concentração com base naquilo que Moltmann compreendeu através de Auschwitz, porém, agora, retratamos aqui o encontro com a fé cristã que surgiu de uma experiência pessoal como prisioneiro de guerra; um momento, atrás do arame farpado, vivido por ele mesmo. Este foi um fato marcante em sua vida pessoal, vivenciado principalmente em Norton Camp ${ }^{48}$. Fato este que ele sempre retorna para legitimar suas argumentações teológicas. É como se depois de fortes tribulações este fosse um marco importante, um constante retorno, um reinício vital, onde após forte sofrimento ele encontrou força e desejo de viver.

Ao retornar sempre para aquele momento hostil, ele consegue refletir que, naqueles anos, a esperança foi a sua única companheira e, também, o motivo de sua vida e de sua liberdade futura. Neste período, passou a refletir sobre a condição humana, a liberdade e a sua relação com Deus. Isto virá futuramente transparecer em sua teologia, destacada por todos como Teologia da Esperança. Prova disso, é uma confissão de sua experiência - sem liberdade - atrás do arame farpado ${ }^{49}$, maneira como ele a relata:

Da experiência de um longo período como prisioneiro de guerra, entre 1945 e 1948, menciono dois perigos da falta de liberdade: A gente experimenta uma hostilidade de fora, contra a qual não tem mais como se defender, e por isso nos recolhemos à nossa concha interior para proteger-nos contra o mundo exterior hostil através da indiferença e da passividade. Mas com isto nossas energias vitais ficam bloqueadas. A gente não tem mais respeito por si mesmo. Deixamos de ter confiança em nós mesmos. Além disso, a gente aprende a conviver com o arame farpado e com a vida sem liberdade. A gente procura apagar-se, para não ter dificuldades. Mas isto

\footnotetext{
${ }_{48}$ Moltmann esteve primeiramente no campo 2226 em Zedelgem, Holanda. Logo após no campo de trabalhos 22 em Kilmarnock/Ayrshire, chegando a Norton Camp somente em julho de 1946. Cf. MOLTMANN, J. A fonte da vida, p. 10-11.

${ }^{49}$ Esta expressão "atrás do arame farpado" faz parte do vocabulário de Moltmann. Ela pode ser encontrada em várias de suas obras.
} 
significa que a gente se submete interiormente. Esta submissão passa a ser dependência e esta dependência tira a capacidade de se tomar decisões. A fraqueza de impulsos evolui para uma apatia geral. A gente não vive mais, apenas se deixa levar. Quando então tudo passou a ser indiferente, a gente não sente mais o arame farpado. Nestes dois perigos, o do autodesprezo e o da acomodação, perdemos a vida e nos entregamos. Mas no momento em que nossa vontade de viver se reacende e em que determinadas experiências, que chamamos de experiências de Deus, despertam em nós a esperança de viver, começamos a nos revoltar contra a apatia dentro de nós e contra o arame farpado ao redor de nós. Nos arranhamos, nos ferimos (sic). Começamos a sofrer conscientemente e a chorar. Os gemidos e o choro dos prisioneiros sempre são os primeiros sintomas de vida neles, não são de forma alguma sinais de morte ${ }^{50}$.

Ao relatar estes dois perigos (autodesprezo e acomodação), Moltmann nos faz perceber que a linha que separa a esperança da desesperança é muito tênue. Este fato faz com que quem esteja em cima dela possa enveredar-se de um lado para outro. Diante desta situação, ou nos revoltamos com a situação e partimos para cima, superando os obstáculos e as adversidades, rompendo de uma vez por todas com o arame farpado, ou nos conformamos com a situação. Ao se conformar, nós nos recolhemos e perdemos a confiança em nós mesmos. Quando a esperança dá lugar à desesperança tendemos a nos apagar e a nos submeter à dependência alheia. O pathos dá lugar à apatia. Por essa razão que, a esperança cristã alicerça-se sempre na fé. Elas são companheiras inseparáveis em meio às turbulências decorrentes da fraqueza humana. Sem elas ficamos volúveis e tudo passa a ser indiferente, não se sente mais o arame farpado, como ele mesmo diz.

Para compreender a esperança atrás do arame farpado que ele menciona, ele nos lança um desafio. Este desafio é reacender em nós a chama da ressurreição e buscar nas promessas de Deus uma justificação para o mundo, de forma a transformá-lo pela força da presença de Deus em nós. "Dessa forma, a fé em Cristo transforma a esperança em confiança e certeza; e a esperança torna a fé em Cristo ampla e dá-lhe vida" ${ }^{51}$. Estamos aqui diante de um fundamento basilar de sua teologia, quando o ressuscitado vem até nós, de forma livre e gratuita, promete-nos um futuro com o seu Reino. Diante da vida que a ressurreição nos traz, calcada pela esperança da cruz, não podemos deixar que

${ }^{50}$ MOLTMANN, J. O Espírito da vida, p. 106. Grifos nossos.

${ }^{51}$ Id. Teologia da esperança. Op. cit. p. 35. 
a apatia venha a tomar conta de nosso ser. Precisamos superá-la, desafiá-la, vencê-la e conquistá-la. Aliás, este é o objetivo da esperança cristã, sustentada na vida que vence a morte, numa certeza pela promessa na vinda do Senhor que vem. É o que desperta em nós a esperança de viver, que nos impulsiona para frente, a ponto de nos lançarmos, definitivamente, frente ao arame farpado e rompê-lo. Somos salvos pela esperança (cf. Rm 8,24).

Refletindo a partir desta confissão, o autor nos remete a algumas indagações: Estamos hoje também atrás de um arame farpado? Será que, enquanto cristãos, portadores da verdade da fé e da ressurreição, não estamos também nós encurvados numa concha, de maneira passiva, indiferentes, protegidos de um mundo hostil? Será esta a missio cristã? Onde está a nossa esperança? Será a esperança passiva, ou embasada numa pro-missio? Que promissio? Que missio?

Responder a estas interpelações é a proposta que seguiu com Moltmann na Teologia da Esperança. Para ele, a promissio cristã fundamenta-se na fidelidade ao Deus da promessa, que por sua vez mantém-se fiel. "Aquele que promete 'mantém' sua palavra e cumpre o que prometeu" 52 . Lança-se aí a uma missio. Ou seja, a missão (missio) se constitui numa promessa (promissio), para ele é de onde parte a esperança ${ }^{53}$. Diante da miséria e da crueldade presente no mundo, onde choro e gemido passam a fazer parte de um cotidiano corrupto e injusto, é lícito descobrir nestes sentimentos sinais de vida em meio à morte e a destruição. São os sintomas de vida que nos fala o autor, que alicerçados na esperança procuram romper todos os paradigmas dominantes em busca da libertação plena e final. Nessas horas, o grito, os choros e os gemidos clamam por uma libertação definitiva, capaz de germinar num lugar hostil fragmentos de esperança.

Vemos assim que estas situações continuam e ainda persistem no pensamento de Moltmann. Ao retornar a elas, ele alinha-se ao Deus solidário e promitente e se sente assegurado por isso. "Em todo fim, está oculto um novo começo. Quando você procura por ele, ele o achará" 54 .

\section{O encontro de Jürgen Moltmann com a fé cristã}

Com certeza, a experiência de sofrimento em meio à guerra, a destruição de sua cidade natal, o tempo como prisioneiro em campo de concentração, o contato com os demais prisioneiros e a maneira com que foram tratados em

\footnotetext{
${ }^{52}$ Id. Experiências de reflexão teológica, p. 86.

${ }^{53}$ Cf. Id. Teologia da Esperança, p. 32.

${ }^{54}$ Id. Vida, esperança e justiça, p. 12.
} 
Norton Camp antecederam o seu pensar teológico e marcaram o seu encontro com Deus de maneira profunda. Notadamente, conforme já dissemos no início, esta experiência de fé e também de abandono da falta de fé ${ }^{55}$ - causa de grande inquietação pessoal - formam o seu locus theologicus inicial. Moltmann se vê numa busca de sentido para a própria vida e na tentativa de encontrar uma resposta para o que acontecia ao redor de si mesmo ${ }^{56}$. Temos aí o encontro de Moltmann com a fé cristã. "O abandono de Cristo por Deus me mostrou onde Deus está, onde ele estava e onde estará comigo em minha vida" ${ }^{57}$.

Numa situação como aquela que relatamos acima, qualquer pessoa se sentiria também abandonada por Deus. Toda uma vida parece estar desmoronada e entregue ao acaso para quem se encontra nesta condição. A vida se encerrou no passado, o presente já não existe e o futuro parece incerto e perigoso. Alguns ideais de vida que pareciam intocáveis e inabaláveis se demonstram frágeis diante de tal fato. Tem-se aí um momento crucial, que nós - que felizmente nunca passamos por experiência semelhante - nunca saberemos e compreenderemos interiormente. O que ocorreu e o que essas pessoas viveram e sentiram na Segunda Grande Guerra são marcas indeléveis que mancham e ferem a história da humanidade.

Ao relatar em vários dos seus escritos que diante do seu sofrimento e do seu abandono ele se identificou com o sofrimento de Jesus na cruz, a ponto de poder exclamar em seu coração "Senhor meu e Deus meu!", representa aspectos sensíveis de uma esperança singular e verdadeira que foi semeada lentamente neste campo de concentração, abrindo um espaço silencioso para uma fé interior. Este sentimento de abandono que ele sentiu e que é comum no

\footnotetext{
${ }^{55}$ Destacamos esta crise interna em Jürgen Moltmann como algo positivo em seu processo, como algo que o faz repensar a sua situação e o sentido da sua própria vida, evidenciado pela experiência de Deus que começava a germinar. Joseph Ratzinger (Bento XVI) diz em sua obra "Introdução ao Cristianismo" que esta é uma situação normal na vida do crente. Estamos diante da dúvida e da fé que interpelam o ser humano diante de Deus. Não se trata apenas da dificuldade de se fazer entender, mas também da insegurança da própria fé; algo natural da condição humana, pois este crer produzido pela fé lança-se ao que não se vê. Para responder a isso, Ratzinger aponta que existe no fiel, primeiramente, uma "ameaça da incerteza"; tudo aquilo que parecia certo e evidente, torna-se frágil e obscurece-se na falta de algo concreto. Significa que, "num mundo aparentemente sólido e blindado, um ser humano se vê confrontado, de repente, com o abismo que se esconde debaixo da estrutura firme das convenções que nos sustentam". Nesta relação entre o ser humano e o mundo não está em jogo apenas parte desta fé, mas o todo desta fé. Esta fé, que pela experiência parece ser sólida, vê-se as voltas com um abismo que a questiona. Cf. RATZINGER, J. Introdução ao cristianismo. São Paulo: Loyola, 2005, p. 33.

${ }^{56}$ Cf. MOLTMANN, J. Experiências de reflexão teológica, p. 18.

${ }^{57} \mathrm{Id}$. A fonte da vida, p. 13. Grifos do autor.
} 
ser humano, o foi, também, por vezes, enfrentado pelo próprio Jesus em sua vida, de sobremaneira, quando sentiu o abandono na cruz, como ele o menciona: “Deus meu, Deus meu, por que me abandonaste?" (Mc 15,34). Há aí uma identificação de Moltmann com Cristo, pois ele sente no crucificado alguém que lhe é próximo.

\begin{abstract}
Cristo - o amigo da peregrinação, que abandonou tudo para procurar as vidas abandonadas. Cristo - aquele que me toma pela mão em seu caminho rumo à ressurreição e à vida. Eu tornei a perceber a coragem de viver. Tomou-me - de modo lento, mas seguro - uma grande esperança na vida plena. Eu ouvi novamente os tons musicais, vi de novo as cores, senti mais uma vez as forças da vida. Naquele momento, eu não me decidi por Cristo, como é comumente exigido por muitos. Mas estou seguro de que, naquele instante e naquele lugar, no escuro buraco da minha alma, Cristo me achou. Posteriormente, me decidi por Cristo e por seu reino e faço isso até hoje. Naqueles dias, o abandono de Cristo na cruz me mostrou onde Deus está presente, onde ele estava naquela noite de chamas em Hamburgo e onde ele estará ao meu lado, aconteça o que acontecer no futuro. Esta convicção não tem me abandonado até hoje ${ }^{58}$.
\end{abstract}

Notamos aqui que Moltmann reconhece nesta ação um ato solidário de Deus capaz de atingir a toda a humanidade. Ele se percebe também como alguém que está incluído nesta ação: "Cristo me achou". Tomado desta experiência ele compreende que toda a dor, a angústia, o sofrimento e a fraqueza humana se encontram atingidos e representados na cruz de Jesus, que transfigura em sua morte todos os limites humanos. Entende que, em seu sofrimento, Cristo converte todo o sofrimento para si. Sendo solidário torna-se também igual, sendo igual torna-se caminho e, sendo caminho torna-se esperança. Biblicamente falando: "o Caminho, a Verdade e a Vida" (Jo 14,6).

É importante se ter claro uma coisa: a solidariedade não está com o sofrimento, e sim, com aqueles que sofrem. Há nisto uma enorme diferença. É um amor que não pode proibir a escravidão e nem a inimizade, mas que sofre a causa desta contradição, podendo carregar apenas a dor e o protesto contra o sofrimento, revelando-se nesta dor. É o que ocorre na cruz de Jesus e que Moltmann reflete teologicamente. Deus deixa que o desprezem, Deus sofre, deixa que o crucifiquem para dar prova do seu amor incondicional e cheio de

${ }^{58}$ Id. Vida, esperança e justiça, p. 11. Grifos nossos. 
esperança. O Pai que ama se corresponde no Filho que ama igualmente, criando, no Espírito, uma correspondência de amor entre Deus e a humanidade, que recusa este amor. Isto gera uma libertação representando algo novo, uma novidade que nasce do amor incondicional de Deus no coração do homem Jesus ${ }^{59}$.

Portanto, ao perguntarmos onde está Deus diante do sofrimento, ou mais precisamente, onde estava Deus nos campos de concentração, em Auschwitz, em Norton Camp e em outros. Onde estava Deus quando aquelas pessoas foram arrancadas de suas casas, violentadas, acorrentadas e jogadas naquele lugar, com fome, sede e frio? Onde estava Deus neste episódio da vida de Jürgen Moltmann? Onde estava Deus naquela noite em Hamburgo ${ }^{60}$ Estas perguntas, segundo ele, só terão uma única resposta: ele estava lá sofrendo com elas. Ele estava lá, junto com ele (Moltmann). Ele era cada uma daquelas pessoas que sofriam naquele campo de Auschwitz e em tantos outros. Para Moltmann, que em seu livro "O Deus Crucificado" faz uma comparação semelhante ${ }^{61}$, qualquer outra resposta seria blasfêmia contra Deus, pois, um Deus impassível, o converteria em um demônio. Um Deus absoluto se converteria em nada e um Deus indiferente condenaria a humanidade à indiferença ${ }^{62}$. Esta experiência vivida por ele o liga de maneira também solidária para com aqueles que sofreram em Auschwitz. "É Deus em Auschwitz e Auschwitz em Deus crucificado" 63 , aludindo ao nome de sua obra.

Este é o fundamento de uma esperança real, tanto transformadora como superadora do mundo e a base para um amor que é mais forte que a morte e que pode sujeitar o morto. É a razão de viver com os medos da história e de seu final e, ainda, permanecer no amor e contemplar o vindouro aberto ao futuro de Deus ${ }^{64}$.

\footnotetext{
${ }^{59}$ Cf. Id. El Dios crucificado, p. 352-353.

${ }^{60}$ Cf. Id. Weiter Raum. Eine Lebensgeschichte, p. 186.

${ }^{61}$ Moltmann relata a história contada por E. Wiesel, já citado anteriormente e que é sobrevivente de Auschwitz, que oferece em seu livro Night, uma expressão comovente para a teologia: "A SS enforcou a dois homens judeus e a um jovem diante de todos os internos no campo. Os homens morreram rapidamente, a agonia do jovem durou meia hora. 'Onde está Deus? Onde está?', perguntou um atrás de mim. Quando depois de longo tempo o jovem continuava sofrendo, enforcado no laço, ouvi outra vez o homem dizer: 'Onde está Deus agora?'. E em mim mesmo escutei a resposta: Onde está? Aqui... Está ali enforcado no madeiro”. MOLTMANN, J. El Dios crucificado, p. 393.

${ }^{62}$ Cf. Ibid.

${ }^{63}$ Cf. Ibid. p. 399.

${ }^{64}$ Ibid.
} 
Toda esta experiência, agora refletida à luz de Cristo, leva Moltmann a questionar-se: "Por que não estou morto também? Para que vivo? O que dá sentido à minha vida? É bom viver, porém é duro ser um sobrevivente. É preciso suportar o peso do luto" ${ }^{65}$. De fato, trata-se ainda de uma culpa imensurável que o percorreu desde o incidente em Hamburgo, quando sua cidade natal foi bombardeada, até os dias de hoje: "Quando essa lembrança me vem à mente, me assaltam temor e tremor" ${ }^{\prime 66}$. Esta libertação que foi proporcionada pela esperança e, especificamente, a esperança cristã, só foi sendo consolidada lentamente, como ele mesmo falou, aproximando-lhe de um encontro com Deus, de um encontro de fé. Percebemos que, esta experiência vivida por ele não se deu de maneira isolada, mas foi percebida, compartilhada e enriquecida com outras pessoas que compartilhavam, juntamente, da mesma situação.

Não ouvíamos acusações. Não nos atribuíam nenhuma culpa. Éramos aceitos como seres humanos, embora não passássemos de números e ostentássemos nas costas as lapelas de prisioneiros. Experimentamos perdão da culpa sem confissão de culpa de nossa parte. Foi isso que nos possibilitou viver com o passado de nosso povo e com as sombras de Auschwitz, sem reprimi-las e sem endurecermos ${ }^{67}$.

Era um período difícil em que todos procuravam se libertar da sensação de culpa que os aprisionava em seus medos. Parece-nos que, neste momento, muito antes da esperança se manifestar o grande desafio era se sentir perdoado, acolhido e aceito. A culpabilidade, mais que o próprio muro, os aprisionava a ponto de questionarem a própria vida e indagarem: "como pode alguém viver com isso?" Para ele, o fato de ter sido salvo não foi uma dádiva, mas uma incumbência, que aos poucos, através de um sentimento de esperança começa a despontar ${ }^{68}$.

O que no início parecia ser um destino cruel tornou-se para nós uma benção de riqueza imerecida. Começou na noite da guerra, mas quando chegamos em Norton Camp raiou o sol para nós. Chegamos com almas feridas, e, quando saímos, "minha vida foi salva". [...] foi Deus quem olhou para nós com os "olhos radiantes" de sua alegria eterna. [...] sentimos que ele olhou para nós com "olhar resplandecente", e sentimos o calor de seu amor ${ }^{69}$.

\footnotetext{
${ }^{65}$ Id. A fonte da vida, p. 10.

${ }^{66}$ Id. Vida, esperança e justiça, p. 10.

${ }^{67} \mathrm{Id}$. A fonte da vida, p. 13.

${ }^{68}$ Cf. Ibid., p. 10.

${ }^{69}$ Ibid., p. 16.
} 
Temos então, que este encontro de Moltmann com a fé cristã vem antes de um encontro com o Deus da esperança, o Deus que vem em Cristo, que se torna próximo e solidário e que o encontra no abismo de sua vida. Este encontrar-se com a fé cristã que surge a partir daí, transforma-se na força necessária para ele continuar vivendo; tem-se, naquele instante, um sentido para a vida e é este sentido que o faz viver e o conduz até hoje.

\section{Conclusão}

Toda a reflexão que Jürgen Moltmann faz sobre a esperança tem a sua origem numa experiência pessoal. Trata-se de algo vivenciado por ele em seu longo período de prisioneiro de campo de concentração, durante e após a Segunda Guerra Mundial, principalmente, em Norton Camp (Inglaterra), que vai aos poucos ganhando espaço na sua vida e dando-lhe respostas, sendo assim, capaz de direcioná-lo a um futuro, que até então, parecia incerto. Ao mesmo tempo em que ele sente na própria pele os efeitos da guerra e na medida em que toma conhecimento das atrocidades nazistas, solidariza-se também com todos aqueles e aquelas que assim como ele foram vítimas da crueldade humana. Num ambiente assim, a esperança foi a sua companheira e o seu refúgio; foi ela que o manteve vivo e, por esta razão, é até hoje a sua companheira inseparável (expressão que ele sempre aponta). Em meio à dor, encontra compaixão; na compaixão, abre-se à esperança; na esperança, encontra-se com a fé; nesta fé, é "achado" por Cristo e se encontra com o Deus da esperança. Para se compreender a teologia que este autor desenvolve, fazse necessário percorrer com ele este caminho.

Deste encontro com a esperança e com a fé cristã é que faz surgir a Teologia da Esperança; na sequência, toda a sua teologia terá este alicerce e esta orientação. Seja no seu início, seja mais tarde quando reflete a parte pneumatológica e trinitária, seja na atualidade com a questão ecológica e política global. Ao refletir sobre a esperança, condicionou a sua teologia dentro de um aspecto contextual, possibilitando uma visão da realidade e uma maneira de transcender a mesma, na perspectiva do Reino, vivido em esperança.

Jürgen Moltmann se sente movido pela esperança, é de onde ele concebe a sua fé e é de onde ele parte com a sua teologia. Reler o seu processo e entender o seu caminho, provoca-nos à mesma experiência, na esperança. 


\section{Referências Bibliográficas}

KUZMA, C. A esperança cristã na Teologia da Esperança. Pistis \& Práxis, Curitiba, v. 1, n. 2, p. 443-467, jul/dez, 2009.

. O futuro de Deus na Missão da esperança cristã: um estudo da escatologia na Teologia da Esperança de Jürgen Moltmann em aproximação com a Teologia Latino-Americana da Libertação no contexto atual. Disponível em: <http://www.maxwell.lambda.ele. puc-rio.br/19888/19888_1.PDF>. Acesso em 07 de agosto de 2012.

METZ, Johann Baptist. Teologia Política. Porto Alegre: Escola Superior de Teologia São Lourenço de Brindes; Caxias do Sul: UCS, 1976.

. Para além de uma religião burguesa: sobre o futuro do cristianismo. São Paulo: Paulinas, 1984.

MOLTMANN, Jürgen. A fonte da vida: o Espírito Santo e a teologia da vida. São Paulo: Loyola, 2002.

. A Igreja como communio. Concilium, Petrópolis, RJ, n. 245, p. 161-163, 1993/1.

- (ed.). Biografia e teologia. Itinerari di teologi. Brescia: Queriniana, 1998.

. Deus na criação. Doutrina ecológica da criação. Petrópolis, RJ: Vozes, 1993.

. El Dios crucificado. Salamanca: Sígueme, 1975.

- Experiências de reflexão teológica. Caminhos e formas da teologia cristã. São Leopoldo, RS: UNISINOS, 2004.

. Geschichte des dreieinigen Gottes, p. 222. Apud: HAMMES, E. J. A cristologia escatológica de J. Moltmann. Teo comunicação. Porto Alegre, 2000, n. 130, v. 30, p. 606.

. My theological career, 1991, p. 170. Apud: MUELLER, E. R. Apresentação da $3^{\mathrm{a}}$ edição. São Leopoldo, 2005. In: MOLTMANN, J. Teologia da Esperança. Estudos sobre os fundamentos e as conseqüências de uma escatologia cristã. 3. ed. São Paulo: Teológica, Loyola, 2005, p. 14-15. 
. No fim, o início. Breve tratado sobre a esperança. São Paulo: Loyola, 2007.

. O Espírito da vida. Uma pneumatologia integral. Petrópolis, RJ: Vozes, 1999.

. Paixão pela vida. São Paulo: ASTE, 1978.

. Temas para una Teologia de la Esperanza. Buenos Aires: La aurora, $[\mathrm{s} / \mathrm{d}]$.

. Teologia da Esperança: Estudos sobre os fundamentos e as conseqüências de uma escatologia cristã. 3. ed. São Paulo: Teológica, Loyola, 2005.

. Vida, esperança e justiça. Um testamento para a América Latina. São Bernardo do Campo, SP: Editeo, 2008.

. Weiter Raum. Eine Lebensgeschichte. München: Gütersloher Verlagshaus, 2006.

PIAZZA, O. F. "MOLTMANN Jürgen”. In: PACOMIO, Luciano; OCCHIPINTI, Giuseppe. Lexicon. Dizionario dei Teologi. Pieme, p. 897-899.

RATZINGER, Joseph. Introdução ao cristianismo. São Paulo: Loyola, 2005.

Cesar Kuzma

Doutor em Teologia pela PUC-Rio Professor do Departamento de Teologia da PUC-Rio: Graduação e Pós-Graduação E-mail: cesarkuzma@gmail.com / ckuzma@puc-rio

Recebido em: 09/08/12

Aprovado em: 05/12/12 